\title{
Transcription and Phonetics
}

\section{Egyptian}

The orthography used in Egyptian words is the standard one accepted by modern Egyptologists, the only exception being the used to represent the 'vulture or double 'aleph', which is often printed as two commas on top of each other.

Whatever the exact sound of the $\mathbf{z}$ in Old Egyptian it was transcribed into Semitic scripts as $\mathrm{r}, \mathrm{l}$, or even $\mathrm{n}$. This consonantal value was retained at least until the 2nd Intermediate Period in the 17th century вс. In Late Egyptian it appears to have become an 'aleph and later, like the Southern English r, it merely modified adjacent vowels. The is the first sign of the alphabetical order used by Egyptologists, and I shall continue with other letters with obscure or difficult sound values.

The Egyptian i corresponds to both the Semitic 'aleph and yōd. 'Aleph is found in many languages, and nearly all Afroasiatic ones. It is a glottal stop before vowels, as in the Cockney 'bo'le' or 'bu'e' ('bottle' and 'butter').

The Egyptian 'ayin, which also occurs in most Semitic languages, is a voiced or spoken 'aleph. The Egyptian form seems to have been associated with the 'back' vowels $o$ and $u$.

In early Egyptian the sign w, written as a quail chick, may have had purely consonantal value. In Late Egyptian, the form of the language which had the most impact on Greek, it seems to have been frequently pronounced as a vowel, either o or u. 
The Egyptian sign written as $r$ was more usually transcribed as 1 in Semitic and Greek. In later Egyptian it seems, as with the 3, to have weakened into becoming merely a modifier of vowels.

The Egyptian and Semitic letters Romanized as h appear to have been pronounced as an emphatic h.

The Egyptian and Semitic h represents a sound similar to the ch in 'loch'. In later times it became thoroughly confused with the letter š.

The Egyptian letter $\underline{\mathrm{h}}$ appears to have represented the sound hy. It too became confused with š.

The letter written here as $\mathrm{s}$ was transcribed as either $\mathrm{s}$ or $\mathrm{z}$.

$\check{s}$ was pronounced as sh or skh. In later times it became very confused with $\mathrm{h}$ and $\underline{\mathrm{h}}$.

$\mathrm{k}$ represents an emphatic $\mathrm{k}$. Inconsistently, I have followed the common practice of Semitists and have employed q to represent the same sound in Semitic.

The letter $\mathrm{t}$ was probably originally pronounced as $\mathrm{t}^{\mathrm{y}}$. However, even in Middle Egyptian it was being confused with t.

Similarly, the $\underline{\mathrm{d}}$ was frequently alternated with $\mathrm{d}$.

\section{Egyptian names}

Egyptian divine names are vocalized according to the commonest Greek transcription-for example, Amon for 'Imn.

Royal names generally follow Gardiner's (196I) version of the Greek names for well-known pharaohs, for instance, Ramessēs.

\section{Coptic}

Most of the letters in the Coptic alphabet come from Greek and the same transcriptions are used. Six extra letters derived from Demotic are transcribed as follows:

\section{us $s \mathrm{~h} \approx \mathrm{d}$ \\ q $\mathrm{f} \quad$ \& $\mathrm{h} \sigma \check{\mathrm{g}}$}




\section{Semitic}

The Semitic consonants are transcribed relatively conventionally. Several of the complications have been mentioned above in connection with Egyptian. Apart from these, one encounters the following:

In Canaanite the sound $\mathrm{h}_{\mathrm{v}}$ merged with $\mathrm{h}$. Transcriptions here sometimes reflect the etymological $\mathrm{h}$ rather than the later h. $t$ is an emphatic $t$.

The Arabic sound usually transcribed as th is written here as $\mathrm{t}^{\mathrm{y}}$. The same is true of the $\mathrm{dh} / \mathrm{d}^{y}$.

The letter found in Ugaritic which corresponds to the Arabic ghain is transcribed $\dot{g}$.

The Semitic emphatic $k$ is written q, rather than $k$ as in Egyptian. The Semitic letter tsade, almost certainly pronounced ts, is written s. In Hebrew from the Ist millennium BC the letter shin is written as š. Elsewhere, however, it is transcribed simply as s, not as $\check{s}$, because I question the antiquity and the range of the latter pronunciation (Bernal, 1988). This, however, causes confusion with Samekh, which is also transcribed as s. Sin is transcribed as ś.

Neither dagesh nor begadkephat is indicated in the transcription. This is for reasons of simplicity as well as doubts about their range and occurrence in Antiquity.

\section{Vocalization}

The Masoretic vocalization of the Bible, completed in the 9th and Ioth centuries AD but reflecting much older pronunciation, is transcribed as follows:

\begin{tabular}{|c|c|c|c|c|}
\hline Name of sign & Plain & with' $y$ & with 1 w & with $\pi \mathrm{h}$ \\
\hline Patah & $\underset{\partial}{\partial} \mathrm{ba}$ & - & - & -- \\
\hline Qåmeș & כ̦ bå & bâ & - & כָָּ båh \\
\hline
\end{tabular}




\begin{tabular}{|c|c|c|c|c|}
\hline Hîreq & bִ bi & ḅִ̂ bî̀ & - & -- \\
\hline Șērê & כِ bē & bê & - & כֵּה bēh \\
\hline$S^{\mathrm{e}} g \bar{o} l$ & 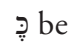 & כֶֶ bệ & - & כָָּ beh \\
\hline Hōlem & כ bō & -- & ¡ֹ bô & כּה bōh \\
\hline Qibûs & כֵ bu & -- & bû & -- \\
\hline
\end{tabular}

The reduced vowels are rendered:

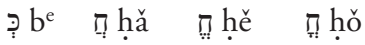

Accentuation and cantillation are not normally marked.

\section{Greek}

The transcription of the consonants is orthodox.

$v$ is transcribed as $y$.

The long vowels $\eta$ and $\omega$ are written as $\overline{\mathrm{e}}$ and $\bar{o}$, and where it is significant the long $\alpha$ is rendered $\bar{a}$.

Accentuation is not normally marked.

\section{Greek names}

It is impossible to be consistent in transliterating these, because certain names are so well known that they have to be given in their Latin forms-Thucydides or Plato-as opposed to the Greek Thoukydidēs or Platōn. On the other hand, it would be absurd to make Latin forms for little-known people or places. Thus the commoner names are given in their Latin forms and the rest simply transliterated from Greek. I have tried wherever possible to follow Peter Levi's translation of Pausanias, where the balance is to my taste well struck. This, however, means that many long vowels are not marked in the transcription of names. 